\title{
ПОРУШЕННЯ АДАПТАЦІЇ СТУДЕНТІВ ПЕРШОГО КУРСУ ДО НАВЧАЛЬНОЇ ДІЯЛЬНОСТІ У ВИЩОМУ НАВЧАЛЬНОМУ ЗАКЛАДІ
}

\author{
В. М. Лісовий, В. А. Капустник, В. Д. Марковський, Г. М. Кожина \\ Харківський національний медичний університет
}

\section{DISORDERS OF THE EDUCATIONAL ADAPTATION OF THE FIRST- YEAR STUDENTS IN HIGHER EDUCATIONAL INSTITUTION}

\author{
V. M. Lisovyi , V. A. Kapustnyk, V. D. Markovskyi, H. M. Kozhyna \\ Kharkiv National Medical University
}

\begin{abstract}
У статті проаналізовано результати комплексного дослідження адаптації студентів-першокурсників до навчальної діяльності, визначено основні чинники ризику виникнення та прояви дезадаптації.
\end{abstract}

In the article the results of the integrated study of the educational adaptation of the first-year students were analyzed, the main risk factors of the beginning and manifestations of the educational dedjustment were determined.

Вступ. Актуальність дослідження причин порушення адаптації студентів молодших курсів до навчальної діяльності у ВНЗ обумовлена тим, що перехід учорашніх школярів до нових форм навчальної роботи (від класно-урочної системи навчання до переважно самостійних занять) виявляється досить проблематичним. Однак недостатня психологічна та практична підготовленість багатьох випускників середньої школи до вузівських форм і методів навчання приводить не тільки до їх неуспішності. Невміння студентів самостійно перебудувати засоби навчально-пізнавальної діяльності відповідно до нових умов навчання, нові соціально-побутові умови викликають у них почуття розгубленості, незадоволення, негативне ставлення до навчання в цілому.

Треба зазначити, що дослідження механізмів порушень адаптації першокурсників до навчальної діяльності, визначення психофізіологічних, психічних і соціально-психологічних проявів дезадаптації, розробка заходів щодо їх запобігання та надання своєчасної професійної допомоги студентам є сьогодні однією $з$ найменш досліджених проблем $[1,2,4]$.

Основна частина. Адаптацію студентів до навчання у вищому навчальному закладі необхідно розглядати як динамічний, багатосторонній і комплексний процес формування навичок задоволення тих вимог, що пред'являються до студента в період навчання та виховання у вищій школі.

Існують об' єктивні та суб' єктивні показники ефективності адаптації студентів до навчання у ВНЗ. До об'єктивних можна віднести: успішність власної діяльності (поточна та підсумкова успішність); стабільність у процесі навчання функціонального стану організму студента (відсутність різких порушень більшості психофізіологічних функцій); відсугність яскраво виражених ознак стомлення при виконанні навчальної діяльності. До суб' єктивних показників відносять задоволеність процесом навчання, а також сформованими в колективі відносинами (психологічним кліматом); прояв студентами активності в навчальній і суспільній діяльностях [ 3,5$]$.

Для визначення основних чинників виникнення та проявів дезадаптації нами було проведено комплексне обстеження 912 студентів I курсу Харківського національного медичного університету обох статей у віці 17 - 24 років, 3 них 603 - вітчизняні студенти (1 група), 100 іноземних з російською мовою навчання (2 група) $\mathrm{i}$ 209 іноземних з англійською мовою навчання (3 група).

Одним із найважливіших соціальних чинників, який впливає на поведінку студента першого курсу, на його взаємини з однокурсниками і викладачами, є зміна соціальної ситуації, необхідність звикання до нових умов навчання, освоєння нової соціальної ролі - студента вищого навчального закладу.

Як показали результати дослідження, основними факторами, що негативно впливають на процес адаптації студентів-першокурсників, $€$ несприятливі побутові умови, недостатне і нерегулярне харчування, різка зміна життєвого стереотипу, входження в новий колектив, згуртування навчальної групи.

( В. М. Лісовий, В. А. Капустник, В. Д. Марковський, Г. М. Кожина 
Згідно з отриманими даними, відрив від домашніх умов важко переносять $6,5 \%$ вітчизняних студентів, 6,0\% російськомовних іноземних студентів, $14,4 \%$ студентів-іноземців, які навчаються англійською мовою.

Не дотримуються звичного режиму дня (навчання і відпочинку) 52,4 \% вітчизняних студентів і 51,1\% російськомовних іноземних студентів. Англомовні студенти є більш дисциплінованими: 3 них порушують режим дня тільки $34,0 \%$.

До факторів, які впливають на труднощі адаптації до навчання на I курсі, студенти відносять: зміну життєвого стереотипу (63,2 \% вітчизняних студентів, $77,2 \%$ російськомовних та $81,1 \%$ англомовних іноземних студентів); труднощі в засвоєнні навчального матеріалу та збільшений обсяг навчального навантаження (83,2 \% вітчизняних студентів, 45,2\% російськомовних та $31,1 \%$ англомовних іноземних студентів); нову систему відносин із викладачами $(15,1 \%$ вітчизняних студентів, 38,0 \% російськомовних і 57,9\% англомовних іноземних студентів); а також труднощі в адаптації до нового колективу $(1,7 \%$ вітчизняних студентів, 17,0 \% російськомовних і 11,0 \% англомовних іноземних студентів). При цьому навчальний матеріал як на заняттях, так і при самостійній роботі задовільно засвоює переважна більшість як вітчизняних, так і іноземних студентів.

Як показали результати дослідження, 30,1 \% з усіх опитаних першокурсників категорично заперечують необхідність психологічної допомоги. Ще 25,9 \% студентів вагаються 3 відповіддю. Решта 44,1 \% першокурсників вважають, що психологічна допомога їм потрібна в першу чергу при вирішенні таких проблем, як подолання інформаційного стресу, адаптація до нових умов навчання, входження в новий колектив, згуртування навчальної групи; рішення особистісних проблем.

При цьому іноземні студенти виявляють більш високий рівень розладів адаптації до навчальної діяльності в порівнянні з вітчизняним студентами. Так, високий рівень дезадаптаціі, що вимагає вживання невідкладних заходів (психологічних і медичних), виявляють у себе 0,3 \% вітчизняних студентів і 0,5\% студентів-іноземців, які навчаються англійською мовою; виражений рівень дезадаптації, що вимагає обов'язкового втручання психологів, проведення програми 3 реадаптації - 1,3\% вітчизняних студентів, 4,0 \% російськомовних і 10,1\% англомовних іноземних студентів; помірний рівень дезадаптації, при якому корисно проведення консультативної роботи фахівців, - 26,2 \% вітчизняних студентів, 48,0 \% російськомовних і 50,2 \% англомовних іноземців.
Як показали результати психодіагностичних досліджень, у 15,8 \% іноземних студентів, які навчаються англійською мовою, виявлено клінічні прояви тривоги (за клінічною шкалою тривоги і депресії Гамільтона), у порівнянні з 7,0 \% російськомовних іноземців і 4,6 \% вітчизняних студентів. Субклінічні прояви тривоги виявлені у $16,3 \%$ англомовних іноземців, $15,5 \%$ російськомовних іноземців і 8,1 \% вітчизняних студентів.

Клінічні прояви депресії характерні для 2,4 \% іноземних студентів, які навчаються англійською, 7,0 \% - російською мовою і 1,4\% вітчизняних студентів, а субклінічні прояви депресії-для 20,1 \%, 16,0 \% i4,5\% відповідно.

Згідно $з$ отриманими в ході роботи даними, як у вітчизняних, так і іноземних студентів, незалежно від мови навчання, мають місце якісні і кількісні гендерні відмінності у взаємозв' язках між емоційним станом і показниками точності і продуктивності розумової роботи. Так, для студентів-юнаків властива відсутність взаємозв' язку між точністю виконуваної роботи і показниками емоційного стану, у той час як у дівчат така картина не спостерігається. Точність здійснюваної розумової роботи залежить від самооцінки власної працездатності та самопочуття, а продуктивність істотно залежить від показника активності і самопочуття у дівчат і від працездатності, активності, тривоги, настрою - у юнаків.

Отримані результати дозволили нам констатувати білышу адекватність самоццінки свого стану у студентівюнаків на відміну від студенток. У студенток існує складна, опосередкована залежність між особистісними та функціональними показниками, тоді як юнаки намагаються бути соціально пристосованими за рахунок витіснення факторів, що викликають тривогу і надконтроль, проте в разі ухвалення важливого рішення коливаються і схильні до невротичних захисних реакцій.

Результати нашого дослідження дозволили охарактеризувати основні прояви порушень адаптації у студентів молодших курсів.

Психофізіологічні порушення адаптації студентів проявляються у зниженні розумової працездатності, порушенні уваги, підвищеній стомлюваності, зниженні швидкості переробки інформації. Виразність психовегетативних реакцій зростає на другому курсі, що більш характерно для чоловіків.

Прояви психічної дезадаптації супроводжуються погіршенням психологічного самопочуття, зростанням астенізації, емоційними розладами, зміною активності, зниженням самооцінки здоров' я, впевненості в собі і пригніченим настроєм. На першому курсі значні зміни мають місце у жінок, а на другому - у чоловіків. 